JURNAL KETAHANAN NASIONAL

Vol. 25, No. 3, Desember 2019, Hal 409-420

DOI:http://dx.doi.org/ 10.22146/jkn.49801

ISSN:0853-9340(Print), ISSN:2527-9688(Online)

Online sejak 28 Desember 2015 di :http://jurnal.ugm.ac.id/JKN

VOLUME 25

No. 3, Desember 2019

Halaman 409-420

\title{
Partisipasi Masyarakat Dalam Kesenian Soreng Guna Meningkatkan Ketahanan Budaya (Studi Di Desa Banyusidi, Kecamatan Pakis, Kabupaten Magelang, Jawa Tengah)
}

\author{
Paramitha Dyah Fitiriasari \\ Pengkajian Seni Pertunjukan dan Seni Rupa \\ Universitas Gadjah Mada \\ Email: paramitha_df@ugm.ac.id
}

\begin{abstract}
Soreng, a piece of folkdance from Magelang, had a special position for its society. This research aimed to understood and analysed the fabulous public participation in Banyusidi village, Pakis sub-district, Magelang district. People became an active participant to arised the existence of Soreng. It was also a good way to increased a cultural resilience.

This research used a qualitative method and ethnography approach. The data was collected by literature study, observation, and interview to the artist and people around it. It had analysed by descriptive analytics ways.

This research found the trichotomy of the artists, society, and tradition. They were three main pillars to preserved traditional performing art in the society. People could develop their skill, expression, and their own creativity. That activity increased the cultural resilience in society. It was an important things because the survival of an art depend on the social participation. Finally, art was supported to cultural resilience rising.
\end{abstract}

Keywords: Community participation, Art, Cultural Resilience.

\begin{abstract}
ABSTRAK
Kesenian Soreng di Kabupaten Magelang memiliki posisi khusus di hati masyarakat. Penelitian ini bertujuan untuk mengetahui dan menganalisis bentuk partisipasi masyarakat Desa Banyusidi Kecamatan Pakis, Kabupaten Magelang sangat besar dan terlihat di dalam kesenian soreng. Masyarakat dengan berbagai peran secara aktif menjadi bagian dalam kesenian soreng guna meningkatkan ketahanan budaya.

Metode yang dipakai adalah kualitatif dengan pendekatan etnografi. Melalui dengan teknik pengumpulan data melalui studi pustaka, observasi dan wawancara kepada beberapa seniman dan masyarakat. Data yang telah dikumpulkan kemudian dianalisis secara analitik deskriptif.

Hasil penelitian ditemukan bahwa trikotomi antara seniman, masyarakat penyangga dan adat merupakan tiga pilar penyangga yang hingga kini dipandang cukup efektif untuk mempertahankan dan melangsungkan tradisi seni pertunjukan di daerah. Masyarakat dapat mengembangkan bakat, ekspresi dan kreativitas dengan porsi masingmasing. Hal semacam itu menyebabkan adanya peningkatan terhadap ketahanan budaya yang tampak di komunitas masyarakatnya. Oleh sebab itu sebuah kesenian tidak dapat bertahan lama ketika sudah tidak ada penyangga atau partisipasi dari masyarakat. Hal tersebut juga sangat identik dengan ketahanan budaya yang juga meningkat dengan adanya kesenian.
\end{abstract}

Kata Kunci : Partisipasi Masyarakat, Kesenian, Ketahanan Budaya. 


\section{PENGANTAR}

Masyarakat desa sangat memahami aspek keberagaman sebagai bagian dari proses kebudayaan dan kemanusiaan. Kesenian sebagai bagian dari unsur kebudayaan dapat menjadi jembatan untuk media berkumpul masyarakat di seluruh kalangan tanpa memperhatikan usia. Kesenian sebagai salah satu bentuk kreativitas budaya masyarakat baik motif maupun bentuknya mempunyai kaitan erat dengan aspek kebudayaan manusia yang lain seperti bahasa, ekonomi, dan sistem tatanan masyarakat di mana kesenian itu tumbuh hidup dan berkembang.

Kesenian rakyat atau tarian rakyat menurut (Jazuli, 1994) adalah tari yang hidup, tumbuh dan berkembang di kalangan rakyat kebanyakan. Kesenian rakyat adalah kesenian khas daerah yang tumbuh sebagai bagian dari kebudayaan masyarakat tradisional daerah, daerah yang dimaksud bisa daerah perkotaan atau daerah pedesaan yang tradisinya masih melekat pada sifat kedaerahannya. Adapun ciri-ciri kesenian atau tari rakyat antara lain adalah bentuknya yang tradisional merupakan ekspresi kerakyatan, biasanya pengembangan dari tarian primitif, bersifat komunal (kebersamaan), geraknya serta pola lantai masih sederhana dan sering diulangulang (Jazuli, 1994).

Kesenian tradisi yang lahir dari lingkungan masyarakat desa memiliki ciri sederhana, bersifat spontan, dan dihayati oleh masyarakat serta berkembang sesuai dengan tradisi pendukungnya. Kesenian dapat terus berjalan dan berlangsung selama masyarakat masih terus mendukung. Kesenian tercipta tidak lebih sebagai perekat kehidupan bersama karena mati hidupnya kesenian tidak bisa dilepaskan dari kehidupan pendukungnya. Kehadiran sebuah genre kesenian karena ada pemain yang memainkannya, ia mati atau lenyap bila para pemain berhenti memainkannya (Brandon, 2003).

Kabupaten Magelang merupakan salah satu wilayah yang jumlah kesenian rakyatnya sangat banyak, satu desa bisa memiliki kurang lebih sepuluh jenis kesenian yang berbeda. Mulai dari kesenian yang muncul beratus tahun yang lalu atau yang benar-benar garapan baru yang muncul tahun 2000-an. Masingmasing memiliki ciri khas yang luar biasa, masing-masing kelompok seolah-olah tidak mau kalah dalam menampilkan kesenian.

Salah satu desa yang berkembang sangat pesat adalah Desa Banyusidi, Kecamatan Pakis yang memiliki kesenian rakyat yang juga tidak sedikit. Setiap tahun masyarakat berlomba-lomba untuk berkreasi dengan ide-ide yang cemerlang. Berbagai acara yang sangat berkaitan dengan kesenian juga sering diselenggarakan. Dalam suatu acara atau hajatan baik desa maupun individu warga masyarakat yang memiliki acara tertentu dapat menyajikan kesenian kepada para undangan dan para tamu. Acara yang paling banyak menggunakan kesenian untuk hiburan di antaranya sunatan, pernikahan, atau sebuah nadzar tertentu. Kesenian yang disajikan jenisnya sangat beragam, tergantung dari yang punya hajat.

Pada umumnya masyarakat menyukai kesenian tradisional yang khas Magelang yaitu Rodat, Topéng Ireng, Warok, Kuda Lumping dan lain-lain. Rodat adalah salah satu jenis kesenian rakyat yang bernafaskan Islam. Kabupaten Magelang merupakan salah satu wilayah yang berada di lingkungan budaya yang dikenal mempunyai pengaruh Islam yang kuat. Topèng Irěng, tarian pemuda yang menggambarkan rasa kebersamaan dan kegembiraan disajikan dengan gerak dan 
iringan yang harmonis menjadikan tarian ini khas. Ditambah lagi dengan kostum yang lain dari pada yang lain seperti suku Indian dengan penutup kepala yang terbuat dari bulu-bulu ayam atau ménthog yang dibentuk sedemikian rupa ditambah dengan pernikpernik menjadikan daya tarik bagi penonton. Warok, jenis tarian ini menggambarkan karakter prajurit yang ditarikan oleh penari putra biasanya berbadan besar, berwibawa, dan berkarakter kuat. Tari Warok ini merupakan pěthilan dari kesenian Reog Ponorogo yang menceritakan tentang kisah Prabu Klana Sewandana ketika diserang oleh pasukan dari Alas Roban yang berujud harimau (Panthera tigris). Kuda Lumping, adalah salah satu jenis kesenian yang hampir di seluruh daerah di Jawa memiliki kesenian tersebut. Kuda Lumping juga disebut Jaran Képang atau Jathilan adalah tarian tradisional yang menampilkan sekelompok prajurit tengah menunggang kuda.

Kesempatan pentas masing-masing kelompok yang tersebar di seluruh desa sangat bervariasi. Namun tidak seluruh desa memiliki seluruh jenis kesenian, namun kesenian yang hampir seluruh desa memiliki adalah kesenian soreng. Kesenian dapat terus eksis dan terus berinovasi karena mereka di dukung oleh masyarakat. Tak heran jika mereka terus menjalin tali silaturahmi antar kelompok seni dan juga antar desa. Kesenian tradisional di era yang semakin modern dapat hilang jika tidak dilestarikan atau ada pendukung yang selalu mengembangkan kesenian. Kondisi di atas merupakan ancaman dan gangguan terhadap ketahanan nasional di bidang budaya. Seluruh warga negara Indonesia harus mampu mempertahankan keberadaan dan kelangsungan budaya daerah terutama di kalangan masyarakat. Dalam mewujudkan ketahanan budaya daerah dibutuhkan peran masyarakat untuk berperan dalam meningkatkan ketahanan budaya daerah (Mantri, 2014).

Tulisan ini memaparkan tentang partisipasi masyarakat dalam menjaga eksistensi kesenian guna meningkatkan ketahanan budaya di wilayahnya, serta menjelaskan faktor-faktor yang mempengaruhi ketahanan budaya. Tulisan ini bertujuan untuk mengetahui sampai sejauhmana keterlibatan masyarakat dalam berkiprah di kesenian tradisional yang ada di wilayahnya, dan manfaatnya untuk dapat meningkatkan apresiasi masyarakat terhadap kesenian tradisional, sehingga dapat menumbuhkan kesadaran untuk melestarikan dan memupuk kecintaan terhadap kesenian tradisional. Nilai yang dapat dipelajari dari seni tradisional adalah dapat memahami tentang semangat (spirit) komunalitas dan partisipasi atau dedikasi.

Partisipasi yang tinggi dari kelompok atau lebih jauh lagi dari masyarakat pendukungnya, merupakan watak dari seni tradisi yang khas dan menonjol. Inspirasi dan aspirasi datang dari mereka dan untuk kepentingan mereka. Dari situlah dapat belajar dan memahami persoalan gotong-royong termasuk kehidupan yang demokratis. Pilar-pilar masyarakat modern sesungguhnya sudah tercermin dalam etika dan moralitas mereka, demokrasi, kebebasan dan keterbukaan, keadilan sosial, pemerataan kesempatan dan pelestarian lingkungan hidup. Secara harfiah, partisipasi berarti turut berperan serta dalam suatu kegiatan, baik peran serta aktif maupun proaktif dalam suatu kegiatan. Partisipasi dapat didefinisikan secara luas sebagai bentuk keterlibatan dan keikutsertaan masyarakat secara aktif dan sukarela, baik karena alasan-alasan dari 
dalam dirinya (intrinsik) maupun dari luar dirinya (ekstrinsik) dalam keseluruhan proses kegiatan yang bersangkutan (Mulyono, 1997).

Ada beberapa indikator dalam masyarakat yang dapat menghambat partisipasi diantaranya adalah kurangnya pengetahuan dan keterampilan menguasai teknik mengatur tari dan bentuk musik yang dapat dijual sebagai seni pertunjukan di industri hiburan dan pariwisata, serta kurangnya pengetahuan dan keterampilan dalam mengatur dan mengemas pertunjukan untuk industri hiburan (Indrayuda,2015). Bentuk partisipasi yang dikemukan tersebut merupakan bentuk partisipasi yang lebih nyata terjadi di masyarakat. Dalam tinjauan partisipatif terhadap seni pertunjukan, keterlibatan masyarakat tidak hanya terbatas dalam pengertian 'ikut serta' secara fisik, melainkan keterlibatan yang memungkinkan mereka melaksanakan penilaian terhadap masalah serta berbagai potensi yang terdapat dalam lingkungannya sendiri. Keterlibatan masyarakat ini adalah keterlibatan yang mengarah kepada tumbuhnya kemampuankemampuan mereka untuk lebih berdaya menghadapi berbagai tantangan hidup tanpa harus tergantung kepada orang lain.

Penelitian ini bersifat deskriptif kualitatif, dapat dikatakan menggunakan pendekatan multidisiplin, sebab meminjam teori dari berbagai disiplin ilmu. Demi memperoleh hasil penelitian yang lebih baik dan lengkap maka dilakukan beberapa teknik pengumpulan data seperti observasi, wawancara mendalam, wawancara bebas, peta dan dokumen (Spradley, 1999). Langkah yang pertama dilakukan adalah kepustakaan merupakan studi awal untuk mendapatkan informasi tertulis dari beberapa referensi artikel, buku, majalah, jurnal, serta makalah yang berhubungan langsung maupun tidak langsung dengan tema penelitian. Observasi dilakukan dengan cara participant observation. Metode ini menjadi pilihan utama sebab sesuai dengan pengamatan secara rinci baik bentuk pertunjukan atau jalinan interaksi antar pelaku dengan masyarakat. Peneliti dapat mengetahui respons penonton dan pelaku sebelum, sewaktu, dan sesudah pertunjukan dengan ikut terlibat langsung dalam berbagai kegiatan.

Participant Observation dilakukan untuk melihat secara langsung aksi pentas dan latihan reguler yang dilakukan oleh masingmasing kelompok. Di samping itu observasi partisipatoris juga dilakukan dengan bergaul dengan lingkungan informan, mendengarkan komentar, dan argumen-argumen informan dengan berusaha untuk tidak memberikan pengaruh apa pun kepada mereka ketika mereka menyampaikan pendapat. Wawancara mendalam dilakukan dengan pengambilan informan yang terdiri dari penari dan kru tari atau pendukungnya juga dilakukan untuk dapat memperoleh data mengenai pandangan mereka tentang kesenian yang dibahas. Pengolahan data yang telah terkumpulkan mulai dari komentar informan, gambar artikel atau teori selanjutnya akan dianalisis secara kualitatif, yakni berupa narasi-narasi yang disusun ke dalam bentuk teks yang diperluas. Ungkapan yang nantinya diuraikan dalam bentuk kutipan juga digunakan agar mendapatkan penggambaran yang jelas dari hasil penelitian

\section{PEMBAHASAN}

\section{Kesenian Soreng Di Desa Banyusidi}

Kabupaten Magelang adalah salah satu wilayah dengan jenis kesenian yang sangat banyak, salah satunya di Desa Banyusidi. munculnya kesenian di wilayah ini tidak terlepas dari peran pendahulu masyarakat atau 
nenek moyang yang lebih dulu ada di wilayah ini. Mereka pada umumnya adalah sesepuhsesepuh yang memanfaatkan kesenian sebagai media untuk menyampaikan pesan. Pada umumnya mereka menggunakan alasan sebagai media dakwah untuk menyebarkan ajaran agama Islam melalui beberapa kegiatan salah satunya kesenian, selain berfungsi juga untuk media silaturahmi. Kesenian itu muncul karena juga untuk menggabungkan atau menyatukan masyarakat di suatu daerah, oleh sebab itu kesenian juga menjadi satu media yang efektif dan cukup efisien dalam waktu untuk mempertemukan masyarakat dalam suatu kepentingan. Dalam hal ini seperti gotongroyong, tukar informasi mengenai perkembangan desa, dan dakwah agama.

Masyarakat lebih tertarik untuk datang menghadiri acara kesenian dibandingkan acara yang resmi protokoler dari instansi atau kantor-kantor pemerintahan. Sementara itu sebenarnya tempat-tempat yang paling mudah dikunjungi masyarakat adalah masjid, namun tidak semua masyarakat juga datang ke masjid. Oleh sebab itu melalui kesenian, masyarakat sekaligus dapat berkumpul dengan tidak pandang usia baik tua maupun muda semua berkumpul menjadi satu dalam suatu wadah kesenian. Kesenian menjadi salah satu mediator pada saat itu untuk mengumpulkan warga untuk dapat menyampaikan informasi. Bentuk pertunjukan tari yang tersebar di Desa Banyusidi, Kabupaten Magelang sangat beragam jenisnya, namun jika dilihat dari jumlah grup ataupun jumlah desa yang memiliki jenis kesenian paling banyak adalah jenis kesenian Sorèng. Hakikatnya tari Sorèng mengandung nilai pemberani atau kepahlawanan. Tari Sorèng pada dasarnya meniru gerak-gerik tari prajurit keraton waktu mengadakan latihan perang.
Sorèng adalah sebuah kesenian tradisional yang memiliki tema kepahlawanan. Kisah ini diangkat oleh warga di lereng Gunung Merbabu dalam hal ini di Desa Banyusidi. Kesenian Sorèng ini menceritakan prajurit dari Arya Penangsang yang sedang berlatih perang dan sedang mempersiapkan diri untuk melakukan perlawanan terhadap pasukan yang dianggap musuh. Masyarakat Lereng Gunung Merbabu, khususnya Desa Banyusidi menjadikan Keprajuritan Arya Penangsang sebagai tokoh dalam kesenian Sorèng dengan alasan yang terbagi beberapa versi di antaranya adalah pertama adalah adanya rasa kebanggaan terhadap sosok Arya Penangsang yang dianggap pemberani, jagoan, dan memiliki daya juang yang tinggi. Oleh sebab itu untuk menghormati keteladanan Penangsang, masyarakat dulu menjadikan Sorèng sebagai kesenian unggulan mereka. Tidak dapat diketahui tahun yang pasti kapan pertama kali Sorèng muncul di Desa Banyusidi, sebab pewaris yang masih hidup sekarang ini tidak bisa mematok tahun kapan pertama kali Sorèng terbentuk. Bagi beberapa kelompok masyarakat, Arya Penangsang dapat disebut sebagai pemberontak namun dijadikan sosok idola di wilayah Lereng Merbabu.

Cerita mistis yang bersumber pada sosok Arya Penangsang juga tumbuh subur di Jipang. Misalnya ada cerita yang mengatakan sesekali aliran sungai Bengawan Sore yang berada dekat makam airnya berwarna merah, yang diyakini berasal dari darah Arya Penangsang. Ada juga di sekitar Bengawan Sore ada pohon kelapa yang kalau malam terdengar ringkikan kuda yang diduga Gagak Rimang, sebab dulu pohon itu menjadi tempat untuk menambatkan kuda Arya Penangsang yaitu Gagak Rimang. Masih banyak hal yang berhubungan dengan cerita Arya Penangsang, salah satu yang unik 
lainnya adalah ketika masyarakat nanggap ketoprak, jangan sampai mengambil lakon Arya Penangsang, bisa kualat nantinya (Wawancara dengan Juru Kunci Makam Gedong Ageng, 29 Mei 2011).

Masyarakat Lereng Gunung Merbabu, khususnya Desa Banyusidi menjadikan keprajuritan Arya Penangsang sebagai tokoh dalam kesenian Sorèng dengan alasan yang terbagi beberapa versi:

Pertama, adanya rasa kebanggaan terhadap sosok Arya Penangsang yang dianggap pemberani, jagoan, dan memiliki daya juang yang tinggi. Oleh sebab itu untuk menghormati keteladanan Arya Penangsang, masyarakat dulu menjadikan Sorèng sebagai kesenian unggulan mereka. Tidak dapat diketahui tahun yang pasti kapan pertama kali Sorèng muncul di Desa Banyusidi, sebab pewaris yang masih hidup sekarang ini tidak bisa mematok tahun kapan pertama kali Sorèng terbentuk. Bagi beberapa kelompok masyarakat, Arya Penangsang dapat disebut sebagai pemberontak namun dijadikan sosok idola di wilayah Lereng Merbabu. Ini diasumsikan bahwa Kecamatan Pakis dan sekitarnya yang masih berada di wilayah lereng Gunung Merbabu adalah bekas atau peninggalan kelompok MMC (Merapi Merbabu Complek).

Diawali dari masa revolusi Indonesia saat adanya re-organisasi militer yang dari gerilya ke bentuk militer yang formal tahun 1950-an, bekas gerilya atau pejuang masuk ke dalam TNI itu diadakan proses seleksi sehingga banyak yang ditolak karena tidak punya ijasah, lalu mereka kecewa dan membuat gerakangerakan yang menentang dan membuat kekacauan di mana-mana. Anggota dari kelompok tersebut tidak memiliki pekerjaan dan sebagian besar adalah merampok, mereka tinggal di daerah Merbabu yang saat itu masih hutan dan sangat strategis untuk bersembunyi. Oleh sebab itu dapat diasumsikan bahwa daerah ini adalah bekas dari persembunyian anggota MMC yang merupakan pemberontak dari masa revolusi Indonesia, sehingga tidak heran jika mengidolakan sosok Arya Penangsang.

Kedua, beberapa sesepuh desa yang masih bisa dimintai keterangan mengatakan bahwa dulu itu wilayah Pakis di Lereng Gunung Merbabu ini merupakan pelarian dari prajurit Jipang Panolan karena sudah ditinggal mati pemimpinnya yaitu Arya Penangsang mati di tangan Joko Tingkir, kemudian mereka lari ke daerah pegunungan yang salah satunya Lereng Gunung Merbabu. Mereka menyebarkan ilmu berperangnya kepada masyarakat sekitar. Meskipun kalah, namun mereka tetap ingin eksis dan tetap menghormati pemimpinnya yaitu Arya Penangsang sehingga tetap digunakan sebagai pemimpin prajurit dalam kesenian Sorèng sampai saat ini.

Ketiga, yang mengatakan bahwa di wilayah Magelang terdapat keturunan Demak (Sunan Kudus) yang lari atau hijrah ke wilayah lereng Gunung Merbabu yang masih berbentuk hutan pada masa itu. Wilayah ini sangat sering menjadi lokasi pelarian sebab wilayah di sekitar Magelang atau Karesidenan Kedu dianggap merupakan tanah perdikan, yaitu tanah yang dianggap bebas atau merdeka tidak terikat oleh aturan-aturan yang mengikat.

Bentuk penyajian kesenian Sorèng di Desa Banyusidi bersifat sederhana baik dalam penari, aspek gerak, iringan, rias busana, waktu dan tempat pertunjukan serta berbagai perlengkapannya. Hal ini sesuai dengan ciri khas tari tradisional yang memiliki sifat sederhana. Tari Sorèng ditarikan oleh 
sekelompok penari laki-laki dan ada juga yang perempuan. Berbentuk tarian massal dengan jumlah penari 17-40 secara bersamaan menari dengan bentuk gerak sama dalam tempo tinggi selaras dengan irama tempo iringan, sehingga tercermin rasa dan nilai kebersamaan dan keterpaduan yang serasi dengan berbagai variasi dan komposisi. Medium utama dalam tari adalah tubuh seseorang yang diekspresikan melalui gerak. Melalui tubuh dan gerak yang dibangun penari berkomunikasi dengan orang lain. Menurut istilah setempat penari Sorèng sering disebut penyorèng yang berasal dari kata nyorèng berarti orang yang menari Sorèng (lihat gambar 1).

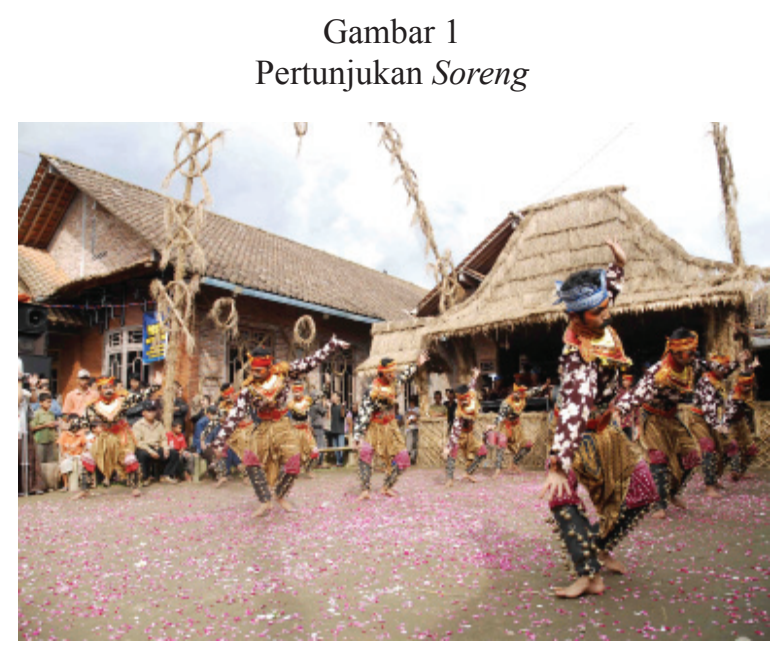

Sumber Foto : Paramitha, 2010.

Seni rakyat memiliki ciri-ciri bentuknya sederhana, ini juga tercermin dalam instrumen musiknya. Iringan atau instrumen yang digunakan untuk mengiringi tari Sorèng, jika di lihat dari jenisnya termasuk alat musik perkusi. Alat-alat dibunyikan dengan irama cepat dan sedang yang dilakukan secara terusmenerus tanpa ada jeda. Pada umumnya alat yang digunakan adalah empat buah bende masing-masing berlaras slendro, satu buah trunthung, dan satu buah bass drum serta simbal. Beberapa tahun terakhir ini banyak grup Sorèng menggunakan lebih dari lima trunthung untuk menambah variasi bunyi. Dalam setiap pentas tari ataupun pertunjukan seni, tata rias dan busana selalu diperlukan untuk membuat para penari menjadi lebih menarik, memperjelas dan memberi tekanan pada garis-garis wajah sesuai dengan karakter yang dibawakan sehingga dapat mendukung ekspresi penari dalam menyajikan tariannya kepada penonton.

Fungsi dari tata rias bukan hanya untuk memperindah diri (muka), juga untuk melahirkan suatu karya dalam bentuk lain sesuai dengan apa yang diharapkan. Meskipun tidak terpaku pada aturan tertentu mengenai bentuk riasan dan tergantung kreativitas masing-masing penari, namun ada keseragaman bentuk riasan yang menjadi kesepakatan bersama. Tata rias tari Sorèng dapat dikategorikan sebagai character makeup di mana salah satu tujuan dasar merias adalah melakukan perubahan sesuai dengan penampilan dan membantu menciptakan karakter baru. Physiognomy juga penting dalam tari Sorèng, di mana karakter dan kepribadian dapat teruangkap melalui make-up (Corson,1975). Sorèng menggunakan bentuk alis yang berat dan tebal, serta menambahkan kumis tebal yang berhubungan dengan energi, fisik atau mental dan juga menambah kesan kekuatan. Hal ini banyak ditemukan pada orang militer, dalam hal ini Sorèng juga merupakan prajurit yang gagah berani.

Pemilihan warna pada riasan wajah maupun juga pada busana pada masyarakat pedesaan juga mempunyai simbol tertentu yang ingin dicapai melalui warna. Dominasi warna merah pada kesenian Sorèng ini menggambarkan simbol keberanian, agresif atau aktif. Sorèng ini adalah tarian yang menggambarkan prajurit yang sedang 
berlatih perang, sehingga diharapkan melalui simbol warna merah yang dikenakan adalah mencerminkan sifat berani, tangguh pada prajurit Sorèng tersebut. Sementara pada surjan yang dipakai biasanya bermotif warnawarna terang, menggambarkan hati yang gembira, mereka menjadi prajurit adalah tanpa paksaan dan menjadi niat bagi mereka sendiri untuk menjadi prajurit.

Tempat pertunjukan sorèng sama seperti pertunjukan rakyat pada umumnya yaitu di tempat terbuka menyatu dengan penonton. Biasanya pentas dilakukan di arena terbuka dan luas misalnya di halaman rumah yang luas atau di lapangan. Namun pada saat ini, pentas dapat disesuaikan dengan kebutuhan bahkan di dalam ruang tertutup. Pertunjukan sorèng memang membutuhkan tempat yang lebih luas seperti di gedung pertemuan, joglo, atau pendapa. Pada umumnya tempat pertunjukan pada bagian tepi dibuat pagar pembatas. Kesenian sorèng yang berkembang dan tersebar di wilayah Desa Banyusidi sangat beragam bentuknya, beda desa sudah berbeda pola tariannya. Gerak memang serupa, tetapi jumlah penari, dan tokoh, iringan, kostum dan asesoris yang digunakan juga bervariasi. Hal tersebut sebab dipengaruhi oleh kreativitas masyarakat yang berkembang.

\section{Partisipasi Masyarakat Dalam Berkesenian}

Partisipasi masyarakat dalam kegiatan kesenian di desa sangat beragam bentuknya. Terutama sebagai pelopor penciptaan kreativitas kesenian. Masyarakat bisa menjadi kunci dan memiliki peran paling penting dalam menggarap sebuah karya seni. Seniman dengan karya ciptanya merupakan asset yang tak ternilai harganya selama mereka masih memiliki daya cipta yang orisinil dan tidak selalu direkayasa (Wibowo, 2007).
Dalam konteks masyarakat Desa Banyusidi, seniman tidak didefinisikan sebagai pembuat seni atau penggarap seni saja, namun juga seluruh anggota masyarakat yang terlibat dalam kesenian di daerahnya. Masyarakat lebih menyukai istilah pelaku seni baik penari, pengrawit ataupun anggota kesenian yang terlibat dalam proses berkesenian, dan mereka memegang salah satu peran penting untuk keberlangsungan hidup kesenian. Satu hal yang tidak bisa lepas dari peran serta masyarakat adalah adanya motivasi dari masing-masing individu atau pelaku seni untuk terlibat dalam kegiatan berkesenian. Motivasi masyarakat untuk dapat mengembangkan potensi yang ada pada dirinya inilah yang dapat menjadikan kreativitas dapat terus digali dan diperjuangkan sesuai kemampuan masing-masing pelaku seni. Kreativitas sangat tergantung dengan motivasi dari seniman apakah akan terus mengembangkan potensi yang ada, atau akan menghentikan proses kreatif tersebut.

Partisipasi berasal dari bahasa latin partisipare yang mempunyai arti dalam bahasa Indonesia adalah mengambil bagian atau turut serta. Sementara dalam Kamus Bahasa Indonesia partisipasi berarti hal turut berperan serta dalam hal turut berperan serta dalam suatu kegiatan (Tim Penyusun, 1997). Dalam hal berkesenian tentu saja peran serta masyarakat sangat diperlukan untuk menunjang keberlangsungan kesenian tersebut. Untuk menggerakkan masyarakat menjadi sesuatu yang sulit ketika mereka tidak ada kesadaran diri untuk mau dan rela terlibat langsung dalam segala hal yang berkaitan dengan kegiatan seni.

Cohen dan Uphoff (1979) dalam Irene (2011:61) memberikan rumusan partisipasi masyarakat yang lebih aplikatif dalam 
Rr. Paramitha Dyah Fitriasari -- Partisipasi Masyarakat Dalam Kesenian Soreng Guna Meningkatkan Ketahanan Budaya (Studi Kasus Desa Banyusidi, Kecamatan Pakis, Kabupaten Magelang)

bentuk sebagai participation of decision making, participation in implementation, participation in benefit dan participation in evaluation. Hal tersebut juga bisa diterapkan di dalam masyarakat Desa Banyusidi, yang terkait dengan kesenian guna meningkatkan ketahanan budaya.

Pertama, participation in decision making atau partisipasi dalam pengambilan keputusan adalah keikutsertaan masyarakat dalam pembuatan keputusan melalui perencanaan kegiatan. Masyarakat dilibatkan dalam perumusan atau proses pembuatan keputusan dengan mengemukakan pendapat atau saran dalam menilai suatu program atau kebijakan yang akan ditetapkan. Pengambilan keputusan di kelompok masyarakat yang kaitannya dengan kesenian Soreng melalui musyawarah mufakat. Masing-masing anggota kelompok memiliki hak yang sama untuk saling mengutarakan pendapat, baik sebelum pertunjukan, saat pertunjukan atau sesudah pertunjukan. Sebelum pertunjukan bisa dilaksanakan saat latihan, atau saat sedang rapat membahas keberlangsungan kelompok kesenian Soreng. Hal yang sering terjadi untuk dilakukan diskusi adalah saat menentukan gerakan tambahan dalam kesenian Soreng, kostum yang akan dikenakan, dan juga sampai pembahasan teknis pemberangkatan rombongan kesenian ke lokasi yang dituju.

Masyarakat anggota kelompok kesenian rutin mengadakan pertemuan sesaat sebelum ada pertunjukan. Mereka saling bermusyawarah untuk mendapatkan keputusan bersama soal rencana pertunjukan kesenian Soreng dilokasi yang sudah ditentukan. Ada ketua kelompok atau kepala desa yang terlibat dalam penentuan keputusan sebelum pertunjukan, hanya saja semua keputusan tetap dikembalikan ke anggota kelompok masyarakat yang terlibat.
Seperti apa yang disampaikan salah satu masyarakat.

"saya senangnya di kelompok ini tu adanya
musyawarah dulu sebelum atau sesudah
pentas mba. Misalnya saja ada tanggapan
dari Jogja, nah kita itu mau pakai kostum
yang mana, mau pakai garapan soreng
yang mana, naik mobil apa naik bis. Nah
yang gitu-gitu semua diomongin dulu”.
(Wawancara Kas, 45 tahun)

Dari kutipan wawancara tersebut, dapat diketahui bahwa seluruh anggota antusias untuk diskusi mengenai kesenian Soreng. Tahap musyawarah untuk pengambilan keputusan tidak hanya dilakukan sebelum pertunjukan, tetapi juga saat pertunjukan. Seperti kutipan pernyataan berikut.

"bisa jadi mba... saat pentas itu tiba-tiba lho panggungnya koq kecil atau koq besar brarti formasi penari harus disesuaikan sesaat sebelum pentas. Nah itu harus diomongin bareng-bareng. Ga cuma karna pak lurah aja”. (Wawancara Rud, 36 tahun)

Segala hal dapat terjadi saat pertunjukan, terkadang rencana yang sudah matang bisa berubah ketika pertunjukan dimulai. Bisa karena faktor panggung, soundsystem, atau ada halangan yang tidak bisa terelakan. Semua itu selalu dikomunikasikan antar anggota kesenian. Tidak selesai di situ, musyawarah juga selalu dilakukan di akhir pertunjukan. Setelah anggota kelompok kesenian pulang ke rumah masing-masing hari berikutnya atau waktu yang telah disepakati mereka kembali berkumpul untuk evaluasi. Apa yang kurang dari pentas sebelumnya, atau ada permasalahan yang harus dipecahkan bersama. Partisipasi masyarakat dalam pengambilan keputusan ini dirasa sangat penting dan banyak manfaatnya untuk kebutuhan kelompok, sehingga diharapkan tidak ada lagi salah 
paham, atau sikap otoriter dari ketua, semua dapat duduk bersama mengambil keputusan secara bersama-sama.

\section{Kedua,participation in implementation} atau partisipasi dalam pelaksanaan merupakan keikutsertaan masyarakat dalam pelaksanaan kegiatan yang berwujud kontribusi. Jenis partisipasi yang kedua ini di dalam masyarakat Desa Banyusidi untuk hal kesenian sangat tinggi, bagaimana mereka sangat terlibat dan berkontribusi yang nyata dalam kegiatan khususnya kesenian Soreng. Kesenian yang mereka ciptakan lebih sebagai kebutuhan bersama, sehingga hidup matinya tergantung dari kesetiaan para pendukungnya (Bandem, 2000). Seperti yang diungkapkan Handoko, ketua Sanggar Warangan Merbabu berikut ini.

"Saya terlibat dalam bidang kesenian di desa awalnya karena bapak itu dulu juga ketua Sanggar Warangan. Karena sering ikut bapak berkesenian, maka otomatis saya juga senang dengan seni. Setelah bapak seda, saya kemudian dipilih oleh warga untuk meneruskan kepemimpinannya. Dengan senang hati saya mau untuk terus mengembangkan kesenian di desa saya, itu tidak ada paksaan lho mbak, itu dari hati saya yang paling dalam" (wawancara Han, 38 tahun).

Ungkapan yang sama juga diungkapkan Ek (34 tahun), pengrawit dari Sanggar Wargo Budoyo, Desa Banyusidi sebagai berikut.

Dari kecil saya suka sekali dengan soreng mbak, karena saya ga bisa nari maka saya memutuskan belajar nggamel. Dari ikut latian dari SMP sampai skarang lulus SMA saya bisa main musik, dulu saya cuma bisa iringan tari soreng tapi sekarang sudah bisa semua mbak. Itu saya belajar sendiri dan sering ikut latihan di rumah pak lurah. Saya mau sendiri mbak, ga ada yang nyuruh tho (wawancara Ek, 34 tahun),.
Ungkapan tersebut dapat menggambarkan bahwa masyarakat yang ikut terlibat dalam kegiatan seni adalah murni keinginan pribadi untuk berpartisipasi mengembangkan kesenian yang ada. Oleh sebab itu partisipasi yang dilandasi oleh motivasi baik pribadi maupun kelompok akan lebih efektif dibandingkan jika masyarakat bergerak karena adanya unsur keterpaksaan. Masyarakat mempunyai semangat yang tinggi dari kesadaran masingmasing individu untuk ikut berpartisipasi langsung dalam memajukan kesenian yang ada di desanya. Partisipasi warga masyarakat untuk memajukan kesenian adalah murni dari diri pribadi mereka sendiri tanpa paksaan dari pihak mana pun. Semangat mereka tampak besar ketika akan ikut pentas dalam sebuah acara baik di dalam maupun di luar desa, antusias yang luar biasa mereka perlihatkan dengan berpenampilan semaksimal mungkin, mempersiapkan diri mereka jauh hari sebelum hari H. Ini menggambarkan kesenian sudah mengalir dalam darah warga masyarakat. Sebuah pertunjukan tidak akan sukses tanpa ada pendukung yang dengan setia ikut menyukseskan sebuah pertunjukan.

Partisipasi masyarakat yang lain juga terlibat sebagai pendukung kesenian adalah orang-orang yang terlibat di dalam pertunjukan, terdiri dari tim pengurus, penari, pemain musik dan vokal, dan pawang atau orang yang dipercaya sebagai sesepuh kelompok. Masingmasing memiliki tugas sebagai berikut.

(1). Pengurus. Pengurus di dalam sebuah pertunjukan merupakan orang-orang yang terlibat di dalam organisasi kesenian. Mereka menduduki posisi sebagai pengurus inti. Dengan mereka ikut serta dalam setiap pementasan, mereka dapat menata pelaksanaan pertunjukan menjadi lancar. Di dalam kerjanya mereka tidak ada pembagian tugas, semuanya 
dilakukan secara bersama dan bergotongroyong demi kelancaran pementasan. Di antaranya adalah menyiapkan akomodasi seperti kendaraan, sehingga para anggota lainnya tinggal berangkat dan pulang tanpa pusing memikirkan alat transpotasi. Bagian lain menyiapkan segala peralatan pentas seperti kostum, atau alat musik sebab para penari tidak akan membereskan semuanya sehabis pentas karena faktor kelelahan. Jika tidak ada yang membantu mengurusi bisa jadi semua peralatan mudah hilang. Tidak ada jarak antara pengurus dan pemain, mereka harus bekerja sama demi keberlangsungan kesenian.

(2). Penari, berhasil tidaknya kesenian, khususnya tarian dalam masyarakat tergantung pada para pendukungnya. Penari merupakan faktor penting terbentuknya suatu jenis kesenian. Sebagai penari tentunya diharapkan mampu membawakan tarian dengan baik, terlebih lagi tarian kelompok, sebab dibutuhkan rasa kekompakan dan harus mengesampingkan kepentingan pribadi dan harus mengutamakan kepentingan kelompok. Seringnya berlatih bersama atau sekedar berkumpul dapat menambah rasa kedekatan antar pemain.

Memang tidak dapat dipungkiri jika dalam sebuah pementasan jumlah anggota penari berkurang. Ini terjadi jika beberapa di antara mereka sudah pindah ke kota atau daerah lain untuk bekerja. Faktor lain karena beberapa penari masih bersekolah, jika musim ujian tiba tentu mereka akan memilih untuk belajar. Namun para pengurus tidak kehabisan akal untuk menyiasatinya, mereka terus melatih para generasi muda lainnya untuk berlatih.

(3). Pemain musik dan vokal. Pemain musik dan vokal adalah bertugas mengiringi jalannya pertunjukan dengan iringan musik dan vokal. Jumlah pemain musik dan vokal adalah tujuh atau delapan orang yang bisa bergantian, tetapi bagi penyanyi atau vokal jarang diganti karena harus yang benar-benar hafal dan menguasai setiap lagunya.

Partisipasi masyarakat di kesenian yang ada di desa sangat beragam bentuknya, serta tingkat partisipasi nya pun sangat beragam. Namun mereka dengan sukarela terus malanjutkan tradisi di daerahnya. Namun, satu hal yang juga penting dalam eksistensi sebuah kesenian adalah penonton. Masyarakat yang tidak terlibat langsung dalam kesenian Soreng, mereka mendukung dengan cara menonton. Terkadang ketika kelompok Soreng harus pentas keluar desa, mereka juga akan pergi mengikuti kemana kelompoknya pentas. Partisipasi penonton akan terlihat ketika sebuah pertunjukan atau pentas dilaksanakan, mereka bahkan datang dari desa atau tempat yang jauh dari lokasi pertunjukan. Tidak jarang juga mereka harus berjalan kaki berkilo-kilo meter dengan medan yang naik turun bukit, terkadang hujan pun mereka terjang demi melihat kesenian kebanggaan mereka. Usia penonton bervariasi, mulai dari dari anak-anak sampai lansia semua berbaur menjadi satu di arena pertunjukan.

Hal semacam itulah juga yang semakin membuat penari atau semua orang yang terlibat dalam seni merasa bangga ketika mereka pentas dan disaksikan oleh puluhan, ratusan bahkan ribuan orang. Penari dan pengiring musik adalah satu kesatuan dalam sebuah pertunjukan, oleh sebab itu mereka mempunyai tanggung jawab untuk dapat memuaskan hati para penonton. Rasa senang yang dibawa penari harus sampai kepada penonton yang masing-masing juga mempunyai selera yang berbeda-beda namun dapat disatukan melalui sebuah pertunjukan yang indah. 
Menjadi primadona dari masyarakat penonton tidak mudah, mereka mempunyai kriteria tertentu untuk menjadikan sebuah kesenian itu adalah idola mereka. namun yang terjadi pada pedesaan khususnya bahwa semua seni yang dibawakan oleh masyarakat desa juga bagi mereka adalah idola yang harus selalu didukung keberadaannya. Bentuk dukungan masyarakat adalah ketika ada pentas mereka datang berbondong-bondong untuk menyaksikan pertunjukan tersebut. Meskipun jarak yang harus ditempuh jauh, namun semangat mereka untuk menonton adalah suatu bentuk apresiasi yang tak ternilai harganya (lihat gambar 2).

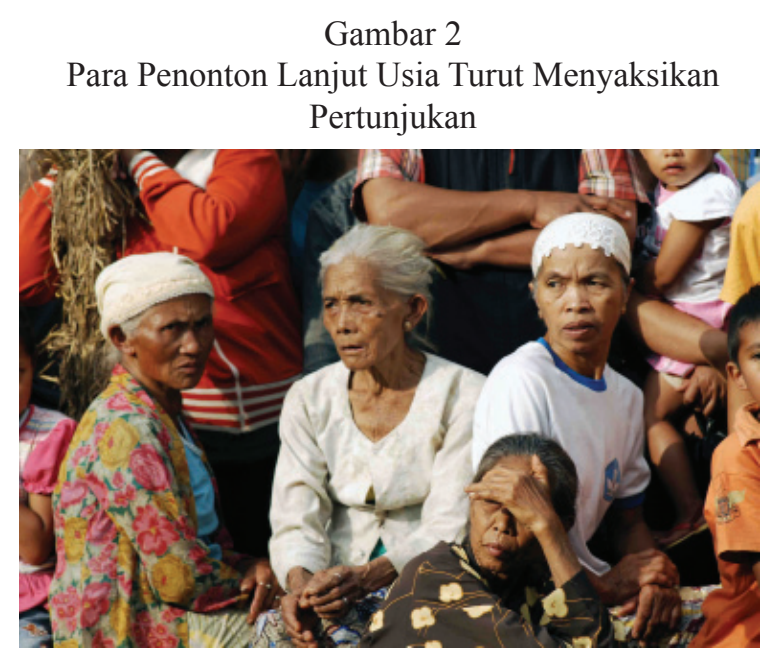

Foto : Paramitha, 2010.

Partisipasi para penonton yang sangat antusias ketika ada grup kesenian pentas ataupun sebuah acara menyelenggarakan pertunjukan dapat terlihat dari cuplikan pendapat salah seorang warga bernama Kisno yang sangat rajin menonton pertunjukan sebagai berikut.

"Saya itu warga Desa Dayugo, tetapi ketika ada pentas baik di dalam desa maupun luar desa kalau tidak barengan dengan acara lain saya pasti nonton. Saya mesti ajak anak dan istri saya untuk liat pentas. Kalau jauh sekali baru naik motor pinjam saudara, kalo dekat ya jalan kaki saja malah enak. Saya tu ga tau ya kok bisa senang kalau habis liat pentas, capek tu rasanya bisa ilang" (wawancara Kis, 50 tahun).

Rangsang-rangsang perasaan penonton muncul secara otomatis karena penari mampu merekayasa kekuatan tubuhnya, intelegensi, dan perasaannya menjadi gerak yang ekspresif (Nalan, 2000). Ada keterkaitan antara penonton dan pelaku seni, penonton fanatik dapat merasakan apa yang sebenarnya yang ada dalam pikiran penari. Bahkan penonton yang hadir pastilah juga mempunyai kesan terhadap kesenian yang disaksikannya. Seperti yang dipaparkan warga Desa Ketundan yang rela mengajak kedua anaknya melihat pentas yang ada di Desa Banyusidi yang kurang lebih jaraknya $5 \mathrm{~km}$ dengan naik sepeda.

"Kula niku saking omah tebih, dalane munggah midhun ming ngajak lare nonton kesenian teng mriki. Soale bocah-bocah niki seneng banget ndelok kesenian. Mboten bosen niku padahal sampun sering nonton teng desa liyane, soale apik mbak.saged dados hiburan" (Wawancara, Sup, 36 tahun).

Pendapat yang sama juga disampaikan oleh warga dari Kota Magelang, yang datang ketika ia mengetahui ada pertunjukan di Kecamatan Pakis.

Saya tahu berita dari teman yang ada di sini, kalau mau ada pentas hari ini. Jadi ya saya datang, soalnya saya seneng banget sama kesenian di daerah sini. Saya paling suka sama Kuda Lumping dan Soreng. Soalnya gerakannya atraktif, jadi kalau saya lagi bosen ga punya uang lagi, saya udah terhibur kalau liat kesenian. Hahaha... (wawancara War, 28 tahun).

Hal tersebut dapat membuktikan bahwa sesuatu yang penting dalam kehidupan yaitu 
tidak punya uang bisa menjadi biasa ketika warga sudah terpikat.

Sebuah pertunjukan tidak akan ada artinya jika tanpa kehadiran penonton, keduanya akan selalu terkait untuk saling mendapatkan kepuasan batin. Partisipasi yang dirasakan oleh masyarakat sekitar Gunung Merbabu adalah sebagai bentuk peran mereka dalam mengembangkan kesenian, mereka tidak hanya sebatas ikut terlibat dalam wujud pentas saja namun juga turut memikirkan bagaimana perkembangan seni di desa mereka dapat terus bertahan dan berkembang. Sebagian dari warga masyarakat tidak segan-segan untuk tergabung dalam sebuah komunitas atau sanggar agar bisa saling tukar pengetahuan atau pendapat yang bisa dilakukan untuk sebuah tujuan bersama.

Ketiga, partisipation in benefit atau partisipasi dalam kemanfaatan merupakan wujud peran dimana dalam keikutsertaan tersebut dapat memberikan manfaat lebih positif bagi pemerintah dan masyarakat. Manfaat dari partisipasi masyarakat dalam kesenian Soreng sangat membawa peran ke pemerintah, dalam hal ini pemerintahan desa, kecamatan sampai kabupaten. Promosi untuk lebih mengenalkan Kabupaten Magelang dengan kesenian Soreng sudah tidak diragukan lagi. Melalui kesenian soreng, nama Kabupaten Magelang juga mau tidak mau akan terangkat popularitasnya. Banyak wisatawan atau wartawan yang kemudian mengunjungi Magelang untuk destinasi wisata. Hari Jadi Kabupaten dan Kota Magelang juga selalu dimeriahkan oleh berbagai jenis kesenian yang berkembang di wilayah Magelang, juga kesenian Soreng yang menjadi ikon Magelang selalu ditampilkan baik melalui pawai, atau pentas masal yang diselenggarakan di alun-alun baik Kabupaten dan Kota Magelang. Adanya beberapa festival yang ada di Kabupaten Magelang juga menambah manfaat khususnya relasi sosial yang besar baik kepada pemerintah dan juga masyarakat yang lebih luas. Banyak seniman seniman besar atau tokoh-tokoh baik pemerintahan atau bukan yang kemudian berpartisipasi bersama kelompok kesenian secara tidak langsung mengenalkan desa ataupun kabupaten menjadi lebih luas secara nasional maupun internasional (lihat gambar $3)$.

Gambar 3

Seniman Dan Budayawan Pada Pembukaaan Festival 5 Gunung Di Magelang

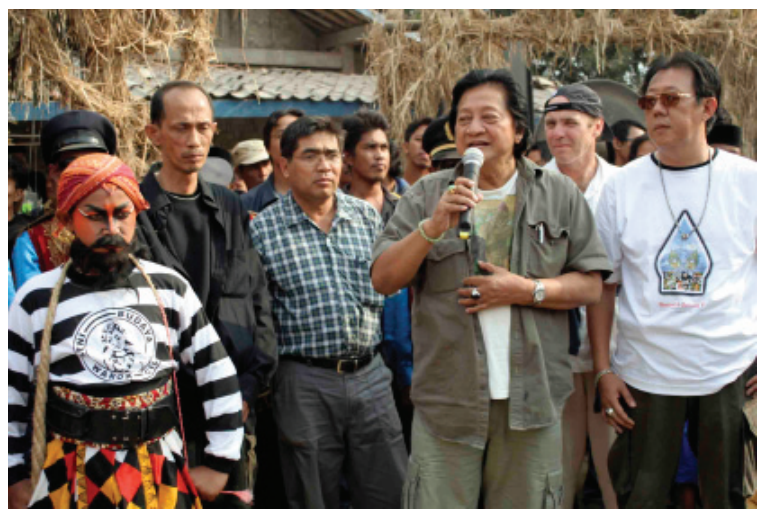

Foto : Paramitha, 2008.

Keuntungan yang di dapat dari partisipasi masyarakat dan kesenian bagi pemerintah tidak selalu soal materi atau uang, namun relasi sosial yang didapat, promosi untuk mendatangkan wisatawan, itu justru mendatangkan manfaat yang jauh lebih berarti. Dikenalnya Desa Banyusidi, Kabupaten Magelang menjadi lebih luas berdampak positif bagi semua kalangan.

Keempat, partisipation in evaluation atau keikutsertaan dalam evaluasi merupakan keikutsertaan masyarakat dalammengawasi dan menilai pelaksanaan hasil-hasil perencanaan. Masyarakat dapat memberikan saran dan kritik tehadap pelaksanaan pemerintahan agar sesuai dengan apa yang telah direncanakan dan mencapai hasil yang telah ditetapkan. 
Seperti yang sudah dijelaskan sebelumnya bahwa ada proses evluasi di masyarakat pelaku kesenian. Evaluasi biasanya dilakukan setelah pertunjukan, evaluasi dapat dilakukan melalui meminta pendapat masing-masing anggota kesenian untuk memberikan masukan atau pendapat sepanjang pertunjukan, bisa dari bentuk pertunjukannya, propertinya, atau suasana penonton, atau lain sebagainya. Semuanya dibahas dan didiskusikan untuk selanjutnya dapat dicari jalan keluar jika terjadi masalah atau ketidaksinkronan. Evaluasi adalah proses yang tidak bisa dilepaskan dari perjalanan kesenian mereka.

\section{Peningkatan Ketahanan Budaya Melalui Kesenian}

Eksistensi kesenian soreng karena adanya partisipasi aktif dari masyarakat pendukung juga sangat berkorelasi dengan meningkatnya ketahanan budaya yang ada di Desa Banyusidi Kabupaten Magelang. Hal ini juga dapat terjadi ketika kesenian diturunkan ke generasi penerus sebagai penerus pelaku budaya (lihat gambar 4 .

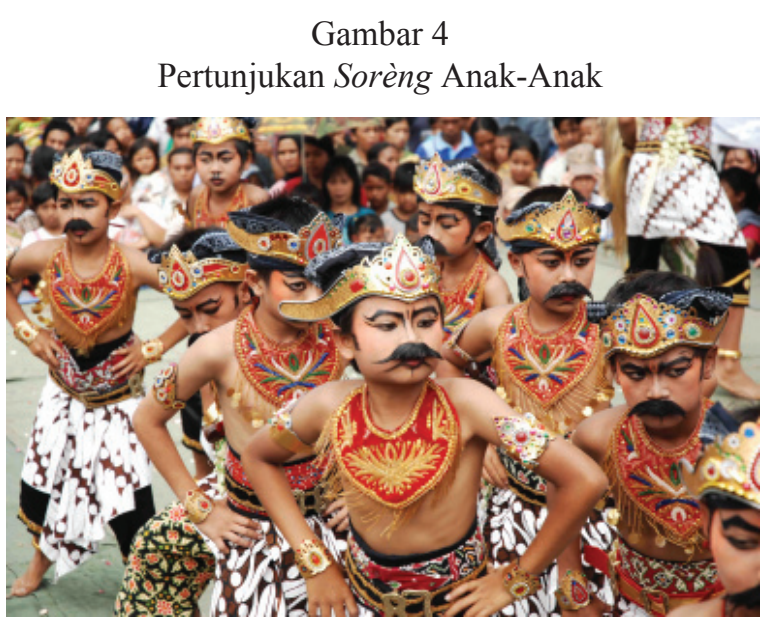

Foto : Paramitha, 2010.

Ada faktor-faktor yang mempengaruhi ketahanan budaya di Desa Banyusidi.
Pertama, faktor tradisi atau keseluruhan kepercayaan masyarakat di Desa Banyusidi. Tradisi masyarakat Desa Banyusidi lahir dari budaya masyarakat adat yang melekat dalam kehidupan sehari-hari. Seperti halnya kesenian Soreng yang merupakan salah satu kegiatan dari sekelompok orang atau masyarakat yang percaya kesenian Soreng ada sejarah yang nyata dan masyarakat sangat mengidolakan sosok Arya Penangsang yang mereka anggap sebagai pahlawan. Dalam tari tersebut tergabung berbagai keterampilan yang mengisi satu sama lain sehingga menjadi seni.

Kedua, pendidikan masyarakat Desa Banyusidi. Pendidikan menjadi faktor penting dalam meningkatkan ketahanan sosial budaya, selain pendidikan formal, masing-masing menempuh cara masing-masing untuk meningkatkan karakter dan moral masyarakat yang kuat dan tangguh. Seperti pelatihan gamelan, latihan tarian bersama orang-orang yang memiliki pengalaman dan praktik yang lebih dulu. Kegiatan ini dilakukan untuk meningkatkan pengetahuan masyarakat dalam kehidupan bermasyarakat.

Ketiga, faktor kepribadian masyarakat yang sebagian besar atau paling dominan bentuk partisipasinya adalah keterampilan terutama seni dan budaya. Hal tersebut menunjukkan kepribadian masyarakat lebih mengarah pada kegiatan seni yang memang menjadi roh dari ketahanan budaya.

Kontribusi kesenian dalam peningkatan ketahanan budaya sangat besar, setiap kegiatan yang berkaitan dengan kesenian sangat berhubungan dengan budaya. Budaya akan bertahan jika masyarakat pendukung dan pelaku kesenian masih ada. Kebudayaan merupakan pola pikir, dan merupakan bagian dari ekspresi hasil karya cipta dan karsa. Kesenian dapat berperan untuk meningkatkan 
ketahanan budaya, tujuan utama dinamika seni dapat melengkapi keberagaman seni dan budaya khususnya di Indonesia. Dengan melestarikan kesenian maka ketahanan budaya akan semakin kuat, dan dapat terhindar dari bentuk - bentuk pengakuan dari negara lain yang mengambil atau mengaku kesenian milik kita menjadi milik mereka. Partisipasi masyarakat dalam berkesenian terhadap ketahanan budaya lokal adalah meningkatnya kesadaran dan identitas budaya lokal masyarakat dalam mempertahankan keberadaan dan kelangsungan seni tradisional, melakukan berbagai macam perubahan tanpa menyalahi kaidah-kaidah orisinalitas budaya lokal, dan melakukan upaya menangkal penetrasi budaya asing yang tidak sesuai dengan budaya lokal (Mantri, 2014).

\section{SIMPULAN}

Berdasar penjelasan sebagaimana diuraikan di atas dapat ditarik simpulan sebagai berikut.

Pertama, kehadiran suatu tari ataupun seni di lingkungan masyarakat merupakan ekspresi estestis dan simbolis yang bersifat individual maupun kolektif yang terkait dengan berbagai macam kepentingan masyarakat pendukungnya. Kesenian Soreng merupakan representasi masyarakat yang mengidolakan sosok Arya Penangsang yang menjadi tokoh utama kesenian soreng. Seni pertunjukan tradisional tidak hanya menggambarkan ekspresi para seniman pelakunya saja, tetapi juga merupakan cerminan dari masyarakat keseluruhan. Partisipasi masyakat dalam kesenian Soreng di Desa Banyusidi, Kabupaten Magelang sangat beragam jenisnya, ada yang menjadi penari, pemusik, pengurus dan juga penonton. Pembagian waktu yang agak sulit karena sebagian besar masyarakat adalah sebagai petani, namun mereka tampaknya tetap semangat untuk terus menjalankan kesenian di desanya. Potensi seni budaya yang tinggi juga menjadi salah satu faktor penunjang eksistensi kesenian.

Kedua, keterlibatan masyarakat dalam berkesenian hendaknya dapat ditambah intensitasnya, dengan ikut berpartisipasi dalam pengambilan keputusan, rapat bersama untuk kemajuan kesenian di desa, semakin menambah jaringan yang lebih luas untuk menambah pengalaman dan kesempatan pentas. Partsipasi masyarakat tidak berhenti, namun diteruskan sampai mereka memiliki generasi di bawahnya yang lebih banyak. Eksistensi seni sangat berpengaruh terhadap ketahanan budaya, mereka saling berhubungan. Ketahanan budaya muncul dalam kemampuan melestarikan budaya silih asih, asah dan asuh bagi pengembangan seni, budaya. Di mana ada kesenian yang berkembang dan memiliki ciri dan identitas wilayah tertentu, maka ketahanan budaya juga akan kuat seiring dengan berjalannya waktu.

\section{DAFTAR PUSTAKA}

Bandem, I Made, 2000, Evaluasi Tari Bali, Yogyakarta; Kanisius.

Brandon, 2003, James R. Jejak-Jejak Seni Pertunjukan di Asia Tenggara. Terj. R.M. Soedarsono. Bandung: P4ST UPI. Corson, Richard, 1975, Stage Makeup, Fifth Edition, New Jersey: Prentice Hall, Inc. Indrayuda, 2015, "Continuity of Tradition Dance : Acedemicians' Intervention of Artists and Perfoming Arts Groups" dalam Jurnal Harmonia Vol 15 Nomor 2 tahun 2015, Semarang: UNNES. Irene, Siti, 2011, Desentralisasi dan Partisipasi Masyarakat dalam Pendidikan. Yogyakarta: Pustaka Pelajar. 
Jazuli, M, 1994, Telaah Teoritis Seni Tari. Semarang: IKIP.

Khairunnisa, Anis., Restu Lanjari, 2016, "Persepsi Masyarakat Terhadap Tari Soreng di Desa Lemahireng, Bawen, Semarang" dalam Jurnal Seni Tari Vol 5 nomor 1 tahun 2016, Semarang: UNNES.

Mantri, Yaya Mulyana, 2014, "Peran Pemuda Dalam Pelestarian Seni Tradisional Benjang Guna Meningkatkan Ketahanan Budaya Daerah (Studi di Kecamatan Ujungberung Kota Bandung Jawa Barat", dalam Jurnal Ketahanan Nasional, nomor XX, Desember 2014. Yogyakarta: UGM.

Mulyono, 1997, "Aspek Manusia dalam Tari”, dalam Jurnal Seni Pertunjukan Bandung: STSI Press.

Nalan, Artur S, 1999, Ed, Aspek Manusia dalam Seni Pertunjukan, Bandung: STSI Press.
Spradley, James, 1999, Metode Etnografi, Terj. Misbah Zulfa Elizabet, Yogyakarta: PT. Tiara Wacana.

Tim Penyusun, 1997, Kamus Besar Bahasa Indonesia, cetakan kesembilan, Departemen pendidikan dan Kebudayaan: Balai Pustaka.

Wibowo, Fred, 2007, Kebudayaan Menggugat, Yogyakarta: PINUS BOOK Publisher.
Wawancara
1. Kas, 45 tahun
2. Rud, 36 tahun
3. Han, 38 tahun
4. Ek, 34 tahun
5. Kis, 50 tahun
6. Sup, 36 tahun
7. War, 28 tahun 